\title{
Review
}

\section{Varieties of political experience: Power phenomena in modern society}

\author{
Gianfranco Poggi \\ ECPR Press, Colchester, 2014, 202pp., ISBN: 9781907301759 \\ Contemporary Political Theory (2016) 15, e6-e10. doi:10.1057/s41296-016-0004-z; \\ published online 21 June 2016
}

Gianfranco Poggi is one of the most prominent social scientists of his time. He undertook the strict path of jurisprudence studies in Italy, earned a $\mathrm{PhD}$ in sociology in America, and then entered the ranks of academia. He soon began his transcontinental life with a career fluctuating between the Old World and the New. His considerable contribution to social research was the consolidation of the discipline in Europe of the 1960s and 1970s as well as the opening of American sociology to European sociological traditions. The overwhelming scientific production, to which he dedicated his best efforts, offered two analytical tools: the re-interpretation of the sociological "classics" (i.e. Tocqueville, Marx, Durkheim, Simmel and especially Max Weber) and the state.

Poggi belongs to that small group of avant-garde scholars who reintroduced the concept of "state" to the research lists of departments of social and political sciences in the English-speaking academe, starting from the mid-1970s. There is something rather paradoxical about this particular fact. The state had already become worthy of interest, as a major social phenomenon, in the United States with the implementation of Keynesian welfare policies during the New Deal. However, American empirical research focused, almost entirely, on subject matter such as machine politics, electoral behaviour, party politics, interest groups, lobbying and political culture. What we call the "modern state" enjoyed no such scientific interest. It was simply left aside and had no room in mainstream social and political research. By using his solid skills as a jurist, Poggi faced this exact subject and even wrote a sociological introduction to the modern state, rich with Weberian social theory but equally updated on the recent developments of European historiographical research. The paradox is that this rediscovery of the modern state, as portrayed by Poggi's contribution, came on the eve of an era which is commonly characterized by its decline. His introduction had a considerable success and soon became a textbook, used by many scholars and university students alike. It was translated into Italian, Portuguese and Spanish. A few years later, Poggi marched

(C) 2016 Macmillan Publishers Ltd. 1470-8914 Contemporary Political Theory Vol. 15, 4, e6-e10 
once again into the same lands of knowledge and dedicated a new book to the state (Poggi 1990). Or better yet two books, since one should include another work, published in Italian in 2014, dedicated to the subject matter of bureaucracy. Nonetheless, we cannot forget the large amount of essays Poggi wrote and scattered here and there throughout the next 30 years of his career. Advantageously enough, EcprPress decided to systematically gather these writings in a special volume aiming at keeping Poggi's reflections up-to-date. Considering the transformations and the apparent decline the modern state has undergone since, this editorial choice deserves credit.

Poggi's primary inspiration was Weberian and it remained such. In this collection of different essays, Poggi pays his debt, intellectually speaking, also to Heinrich Popitz's sociopolitical anthropology. He pays it by concluding his book with the English translation of a book chapter by the same Popitz. The selected chapter addressed the concept of power, and this inclusion is uniquely generous: unicuique suum tribuere. Furthermore, the conclusion is also coherent in relation to the parabola that had been outlined from the beginning of the book. Three chapters precede these conclusive remarks, before addressing the experience of modern statehood; the former discuss broader categories such as the meaning of the 'political' and the nature of power.

Poggi travels far away in time throughout his analysis. He takes off, in the first chapter of his book, from the Greek polis which he considers as a rule technique, based on language and reason. This ancient experience continued to intrigue generations to come because it was perceived as a "horizontal political practice". It was in evident contrast with the modern state, which in its turn, was theorized by Machiavelli, Hobbes, Hegel and many others, and characterized by a distinctive "political verticality". While the polis entailed no division of political labour between its members, the state was rigorously hierarchical; there are leaders and subjects, a minority that holds means of coercion and rules over a majority, which is requested to defend the collectivity and its identity whenever menaced with attack. This division of labour can be demonstrated in many ways. This is also true for the exercise of political power, in a more or less intense and pervasive way. The book dedicates much space to critically discuss all this. There would be just one thing to bring into question: To what extent was the Greek polis horizontal? Was it really so different from the experience of the modern state?

The Greeks were sophisticated promoters of their invention. They successfully delivered the polis to future generations as a glorified, not to say ideal, form of government. Nevertheless, as far as we wontedly distinguish their democracy from our own placing the democracy of the ancient in comparison with that of the modern, and while classifying the first as unrealisable ideal in our overly complicated and densely populated world, we must pay attention to a simple fact: the Greek polis concerned relatively small communities that were not shy of showing brutal force and of using coercion. The polis was inhabited by a minority 
of citizens who governed a majority of non-citizens, namely women, slaves, metics and aliens. And neither was the minority truly equalitarian. After all, the most illustrious praise of their way of life, according to Thucydides, was expressed by Pericles, who was not a tyrant but most certainly a demagogue. Perhaps the main lesson we have learnt from the ancient Greeks is to represent power with words that are more attractive than its actual practice.

However, it is not the only thing worth mentioning. The political experience of Western societies also inherited from the Greeks a number of coercion-mitigating forms of government. The most refined is that of the representative rule: the one to lead is elected by those who put themselves under his rule. The latter enjoy personal autonomy in several fields: economy (the market), individual conscience and civil society. Moreover, the ruled can also bring political power into question within the boundaries of public sphere. Hence, something of Greek horizontality was indeed handed to us; and it is not unthinkable that, despite humanity's dramatic failures, we did overcome some parts of their legacy. Nowadays, who would ever dare, at least in western societies, to execute Socrates? It would not be democratically correct. We have developed subtler techniques to silence our uncomfortable voices.

Poggi's discussion on power continues in the two following chapters. In his view, while staying faithful to Weberian teachings, power is unidentifiable with any specific, visible andlor quantifiable resource. It is rather a form of asymmetric relations between people, which become variously institutionalized. Furthermore, these relations possess the capacity to sustain the life of the collectivity. This exact analysis serves to open the discussion about the idea of the modern state, as developed in the following chapters. As always, old dilemmas reemerge. The first one concerns the image of the state as a means of oppression in comparison to the Hobbesian idea of the state being a benevolent monster (i.e. Leviathan) that people's lives would be inconceivable without. An idea that was followed by Hegelian thought which considered the state to be a superior form of coexistence.

Poggi strolls freely between Scylla and Charybdis, while offering not an idealized normative interpretation of the state but a sociologically and historically based version of it. The modern state, as invented by the West, he writes, is a unique manifestation of the accumulation and exercise of "social power where a group is in a position to control, activate, block the activities of other groups within the same society by availing itself of its own privileged access to means of coercion" (pp. 54-55). Where, nevertheless, does this social group's uniqueness lie? On the one hand, it features the quantity of power it accumulates and exercises as well as the asymmetry that is constructed between the rulers and the ruled. On the other, there exist the multiplicity of restraints, limitations and counterbalances that protect the latter from the former while seeking to avoid conflict. The chapters dedicated to the state thus offer a precious explanatory excursus of the restraints that became intertwined in and throughout European history. 
The state separated itself from the civil society that, following a limited number of enlightened intellectuals, took steps away from its rulers and began claiming proper autonomy. The modern state, from time immemorial, subjected its own power to the law with its formal rules and impersonal world of procedures. Consequently, subjects of the modern state have gained the legal condition of citizens (and the one of tax payers) and enjoy a formally recognized ownership of rights as well as the status of active stakeholders, to some and changeable extent, of modern statehood. In addition, Poggi, confronting himself with Habermas, discusses one of the most stressing challenges to which western rulers are called: the public sphere. In the following chapter, Poggi focuses on another essential element of Western society: the conflictual relations between the political power and the economic one. The tension between them is the outcome of a long and tortuous process of differentiation which has generated a cyclical and crucial mechanism of power-bargaining. Therefore, it was highly expected to find a specific chapter addressing the separation of powers (political, economic and religious). This is what we usually call "secularization". The state gradually freed itself from ecclesial authority and took its role and place in society by offering its own system of, often bloodthirsty, religious rites.

Poggi's conceptual and sociological trajectory comes to an end with the Peace of Westphalia; a decisive moment in the process of state-making. The imprinting of the European modern state resides in its legitimate monopoly on coercion. As suggested by Norbert Elias, this was the outcome of a process of monopolization, not only of coercion but also of land. The accumulation of land was an inherent part of its identity. Nevertheless, a moment arrived when the opposing inclinations of states to possess power, occupy lands and rule men could not avoid collision. The horrific devastation of the Thirty years' War did not teach states to give up war that would have been too much to ask - but at least it made them acknowledge each other's sovereignty and see themselves as parts of the same geopolitical system of balance and renounce their imperial ambitions. It was a partial cessation, we know, because these same ambitions reappeared every so often but were diverted out of the Continent.

Gianfranco Poggi belongs to the lineage of enlightened intellectuals who, after the terrible events of the last century, have to content themselves with milder criticism. Each of the chapters dedicated to the state ends with a consideration of what is now happening in today's world. This book, in an exceptionally wise way, spares us terms such as "crisis" and "decline". Instead, it offers punctual observations on contemporary events. It approaches the illusive submission of politics to rights and the rule of law; it analyses the public sphere tendency to get slimmer and slimmer or better said it portrays its anorexia. The book also addresses the overflowing assaults by neoliberalism in light of its failures (Is it by any chance a new form of fundamentalism?). In addition, it faces the spaces the economic power has gained at the expense of the political power. Poggi reasons as a 
sociologist; therefore, he avoids any form of prophecy. He keeps himself within the bounds of historical observation. Power struggles are never definitively settled. Neither is the state.

The last pages of this unpretentious, and equally dense, book are dedicated to Max Weber, especially to his two renowned conferences on 'Science as Vocation' and 'Politics as a Vocation' (Weber 1946). Poggi opportunely contextualizes Weber's words. Weber was an intellectual too sophisticated to fall into the trap of coarse nationalism. But he did believe in Germany while the country was crumbling into pieces with the fall of the Bismarckian Reich. Here Poggi shows how Weber, during the abovementioned conferences, did not reason as a political scientist, but rather as a politician. He was, most evidently, involved in the political hardships the country was facing in that particular period. One last precision is intended to help some of readers to avoid inappropriate and superficial use of terms. The concept of "charisma", its theorization, as well as valuable considerations on leadership, are found in other parts of Weber's work. The great German sociologist, on that occasion, speaks to an audience of university students to whom he addresses, with a certain degree of emotion, an invite to keep believing in politics' potentials and most surely, not to put their trust in the already ongoing irrationality of the time.

In this book, Gianfranco Poggi also provides evidence of his keen intellectual endeavour and of his sociological savvy. Waiting for someone to select his many writings and to gather them into a well-arranged anthology and maybe above all to give them a proper reading was truly worthwhile. Thank you, Gian.

\section{References}

Poggi, G. (1990) The State: Its Nature, Development and Prospects. Cambridge: Polity.

Weber, M. (1946) From Max Weber, tr. and ed. by H. H. Gerth, and C. Wright Mills. New York: Free Press.

Alfio Mastropaolo

University of Turin, 10124 Turin, Italy almastro@unito.it 